\title{
Article
}

\section{The police, sex work, and Section 14 of the Policing and Crime Act 2009}

\author{
Kingston, Sarah and Thomas, Terry \\ Available at https://clok.uclan.ac.uk/31289/ \\ Kingston, Sarah orcid iconORCID: 0000-0002-9226-1915 and Thomas, Terry \\ (2014) The police, sex work, and Section 14 of the Policing and Crime Act \\ 2009. The Howard Journal of Criminal Justice, 53 (3). pp. 255-269. ISSN 0265- \\ 5527
}

It is advisable to refer to the publisher's version if you intend to cite from the work. http://dx.doi.org/10.1111/hojo.12060

For more information about UCLan's research in this area go to http://www.uclan.ac.uk/researchgroups/ and search for < name of research Group>.

For information about Research generally at UCLan please go to http://www.uclan.ac.uk/research/

All outputs in CLoK are protected by Intellectual Property Rights law, including Copyright law. Copyright, IPR and Moral Rights for the works on this site are retained by the individual authors and/or other copyright owners. Terms and conditions for use of this material are defined in the policies page.

\section{CLoK}

Central Lancashire online Knowledge www.clok.uclan.ac.uk

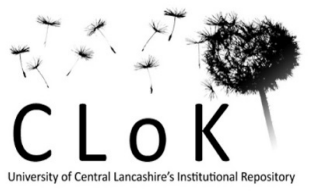


Submission to Howard Journal of Criminal Justice

\title{
THE POLICE, SEX WORK, AND SECTION 14 OF THE POLICING AND CRIME ACT 2009
}

\author{
SARAH KINGSTON \\ and \\ TERRY THOMAS
}




\begin{abstract}
This article considers the origins and aims of section 14 of the Policing and Crime Act 2009 and the offence of paying for the sexual services of a prostitute who has been subject to exploitative conduct; this offence is one of 'strict liability'. Section 14 was implemented on $1^{\text {st }}$ April 2010 and using the Freedom of Information Act the authors have attempted to show the number of times s.14 has been used by the police in England and Wales since the act became law; how the act has been used and the outcome of the use of this section.
\end{abstract}

Key Words: Policing and Crime Act 2009, Strict Liability, Sex Work 


\section{Introduction}

The Policing and Crime Act 2009 s14 has amended the Sexual Offences Act 2003 by adding a new s53A. The new section makes it an offence in England and Wales to pay for the services of a prostitute who has been coerced into providing sexual services; the section was implemented from $1^{\text {st }}$ April 2010. The new offence is one of 'strict liability' making it irrelevant whether the person concerned had any intention to offend or even knew there was coercion going on.

This article considers the background to this law and its origins and what we know about its enforcement by the police. Using the Freedom of Information Act 2000, we made a request to all 43 police forced across England and Wales to determine whether the strict liability law has been used since its introduction and the reasons why. From our requests, we suggest that the law that was enacted to tackle demand and increasing concerns over sex trafficking, is either not needed, or is needed by has not being utilised appropriately.

\section{The Origins of Section 14}

Although there is no mention of it in the Act section 14 is aimed at trafficking and the victims of trafficking for purposes of sexual exploitation; it is also about an overall aim of reducing the demand for prostitution which is seen to be 'fuelling' sex trafficking. This approach closely followed the Swedish model of dealing with the demand side of prostitution (Home Office, 2008). In Sweden the purchase of sexual services has been criminalised across the board regardless of coercion through the 1999 Swedish Prohibiting the Purchase of Sexual Services Act. In the UK it has now been selectively criminalised by section 14 if the person selling the service has been the subject of coercion. 
The introduction of this new legislation emerged from a political context which began reviewing sexual offences laws. In the white paper Protecting the Public which formed the basis of the 2003 Sexual Offences Act the government said that it wanted to review issues surrounding prostitution; in particular it wanted to look at issues of exploitation, organised criminality and the drug abuse associated with prostitution (Home Office 2002: para.73). The 2004 Home Office publication Paying the Price: a consultation paper on prostitution duly looked at all aspects of prostitution focussing on the three key issues of prevention, protection and support and justice. The Consultation paper also outlined the wider case for demand reduction:

prostitution can only exist because there is a demand for it... a coordinated strategy designed to reduce its prevalence must address demand as well as tackle the factors that lead individuals to become involved in its supply

(Home Office 2004: para.1.7)

and the aim should be:

to deter those who create that demand (Home Office 2004: para.1.7)

In the UK two further Home Office reports followed up the pursuit of a reduction in demand. The first drew up A Coordinated Prostitution Strategy (Home Office 2006) which sets out action to be taken by central government and local partnerships to tackle prostitution and was based upon responses to Paying the Price. This strategy included the five key aims of prevention, tackling demand, developing routes out, ensuring justice and tackling off street prostitution.

The second of these aims - tackling demand - was the result of a six month review to just examine 'demand'; it reported in November 2008 (Home Office 2008). 
This review undertook an audit of enforcement and prosecution practice in England and Wales to identify best practice, an assessment of academic research on the purchasers of sex, an evaluation of approaches to tackle demand in nine other countries and Ministerial visits to Sweden and the Netherlands to see how differing approaches have been taken. The point was made again that:

to truly tackle the problem of commercial sexual exploitation more needs to be done to target those who contribute to the demand, those that pay for sex (Home Office 2008, p.9)

There was no suggestion that the purchase of sexual offences should be criminalised in its entirety and the more selective approach was taken that:

The Government should consider introducing a specific strict liability offence of paying for sex with someone who is controlled for another person's gain, in order to protect vulnerable individuals, for example those who have been trafficked or exploited by any other means (Home Office 2008, p.9)

The reasons behind the UK government's reluctance to fully criminalise the purchase of sex fully stemmed from concerns that UK public attitudes were deeply divided. Despite Ministerial support to follow the Swedish model, which criminalised the purchase of sex in 1999, the Home Office concluded that 'it would be a step too far at this time, given the relative size of the UK sex industry compared to that in Sweden and current public attitudes in the UK' (Home Office 2008, p.13).

Links between demand and human trafficking emerged throughout this review and during the consultation period, whereby official documentation suggested that demand fuelled trafficking for sexual exploitation. According to the Home Office's (2007c:31) UK Action Plan on Tackling Human Trafficking: 
A key element of this new approach to prostitution is to focus not only on those who exploit individuals through prostitution, including the traffickers, but also to address the demand side ... to target men who might use massage parlours, saunas or other kinds of brothel, through men's magazines, websites or other targeted media using advertisements which raise awareness of trafficking for sexual exploitation and warn of the risks involved.

The same point was made in the UK's published trafficking strategy

A key element in disrupting the market for trafficking and reducing its profitability is tackling demand by targeting those that pay for sexual services from trafficked women (HMG 2011:para.94)

At an international level the Council of Europe had endorsed this approach:

Each Party shall consider adopting such legislative and other measures as may be necessary to establish as criminal offences under its internal law, the use of services which are the object of exploitation as referred to in Article 4 paragraph a of this Convention, with the knowledge that the person is a victim of trafficking in human beings.

(Council of Europe 2005: Article 19)

The fear was that this selective or targeted approach to criminalising the people who purchase sex form a coerced person was a Trojan horse to start criminalising all people who purchased sex and that the law was not about the coercion or the unnamed trafficking but only about demand reduction in the name of morality (Carline 2010 and 2011). Furthermore, criticisms have been made about the consultation and review of prostitution related offences, in that the whole review was biased from the start and was influenced by a particular strand of feminism (Kingston, 2010). Rather than based upon solid evidence and a robust review of the literature, it has been argued that the law was developed in a biased way. 


\section{The Parliamentary Debate}

The debate in parliament recognised the 'historic' significance of the discussions and

Alan Campbell under- secretary of state for the Home Office made the case:

The measure is important, and people will look back on it as a major stepping stone in social reform ... some Bills may seem more important than others. I cannot remember working on a Bill that is more important than this one. People who are serving on this Committee will look back on the measure in the future, when strict liability is working, when we would have reduced the demand for prostitution, helped women out of prostitution and helped to tackle some of the worst examples of exploitation and trafficking, and be proud of the work that they have done on the Bill (Hansard HC Debates Public Bill Committee 11th February 2009 col 304).

The question was raised in the Public Bill Committee in its briefings on the Policing and Crime Bill that the Home Office had commissioned a rapid evidence assessment of relevant research made by a University at the request of the Home Office; the review Tackling Demand for Prostitution had made mention of:

a rapid evidence assessment (REA) of research available on sex buyers, conducted by the University of Huddersfield to be published shortly.

(Home Office 2008, p.11)

But no one had ever seen this Rapid Evidence Assessment and no publication took place. As a result a number of politicians and organisations raised their concerns that the Government has failed to provide the evidence which they claim supported the introduction of a strict liability offence.

Dr Evan Harris for the Lib-Dems said: 
The government are relying on something that is not published and even if it had been published it was not peer reviewed (Hansard HC Debates Public Bill Committee 6 February 2009 col 282)

Paul Holmes (Lib Dem) argued that:

If a systematic review of the evidence has led the Government down the path to a radical statement of intention, which might, or might not, work, and may make the situation worse, that evidence should have been published so that we could look at it properly. Instead, we receive assertions from the Government that they have looked at the evidence and that it leads them in such a direction. However, they have not published the systematic evidence on which they say the provision is based. That is no way in which to proceed with a major change in the law that introduces a strict liability offence. (Hansard HC Debates Public Bill Committee 10 ${ }^{\text {th }}$ February 2009 col 294)

These concerns demonstrate widespread consensus that legislation should be based upon evidence. As the Human Rights Joint Committee (2009) explains:

As we have said on a number of previous occasions, legislation should be firmly based on evidence. We consider this to be particularly important when new criminal offences are proposed, to show why the existing criminal law is inadequate to deal with the targeted conduct and how the proposed new offence tackles the behaviour in a proportionate way. In our view, it is even more imperative when the proposed new offence is one of strict liability. (Paragraph 1.28)

In addition to concerns over the evidence base of this law, criticisms were also raised about the remit of the offence and the specific terms of law. The Bar Council suggested that the terms of the offence could mean that 'a defendant may be found guilty in circumstances where he could have no idea at the time that he was committing the offence' and that in their view 'the proposed clause as currently drafted is unworkable, wrong in principle and will create unfairness' (cited in Politics.co.uk 2009). 
As a result of these criticisms the government proposed an amendment to the wording of the offence, replacing 'controlled for gain' with 'force, threats (whether or not relating to violence) or any other form of coercion practises ... [or] deception’ (Home Office 2009, p.1), suggesting that this would prevent the offence from 'applying more widely than intended' (Jacqui Smith cited in BBC News 2009, p.1).

\section{The Law}

The wording of the section is worth citing in full:

Section 14 Paying for sexual services of a prostitute subjected to force etc: England and Wales

After section 53 of the Sexual Offences Act 2003 (c. 42) insert53APaying for sexual services of a prostitute subjected to force etc..

(1) A person (A) commits an offence if-.

(a) A makes or promises payment for the sexual services of a prostitute (B), (b) a third person $(C)$ has engaged in exploitative conduct of a kind likely to induce or encourage B to provide the sexual services for which A has made or promised payment, and .

(c) $\mathrm{C}$ engaged in that conduct for or in the expectation of gain for $\mathrm{C}$ or another person (apart from A or B).

Strict liability in law means that a person is considered to be guilty of an offence without the requirement to prove that the person had the necessary mens rea. Only the actus reus is required for an offence of strict liability to have been committed. There can be no defence of mistake or due diligence, i.e. the person is guilty of the act regardless of any mistakes they may have made or if they took steps to prevent the offence being committed. Thus, such offences are easier to enforce as there is no need to prove mens rea and they may save court time, as people may be more likely to plead guilty when they realise there is no need for a guilty mind to be established by the prosecution. In this sense, strict liability offences can be beneficial to victims of 
crime who do not need to go through what can sometimes be a difficult court process in order to establish guilt.

Yet strict liability offences can cause a number of problems for both the defendant. The pressure group Liberty had concerns over strict liability especially 'in situations where there is no way of knowing whether a person is 'controlled for gain"' (Liberty 2009, cited in House of Commons 2009). These difficulties of determining whether a person has been controlled for gain are similarly echoed by the Home Office (2008:14) when it acknowledges 'the practical difficulties in proving whether a defendant knew if a woman was controlled or not'. In addition, Chief Constable Tim Brain expressed concerns about the police's ability in 'gaining sufficiency of evidence to merit a suitable number of prosecutions' (cited in Whitehead 2009, p.1). Given that both the police and Home Office acknowledge difficulties in determining whether a person is the victim of coercion, force or threats, and whether a defendant knew of this coercion there must be serious implications for the justification and fairness of the offence (Kingston, 2010).

It may also be suggested that the new offence goes against Human Rights law, in particular Article 6 (2) of the European Convention on Human Rights which states that "Everyone charged with a criminal offence shall be presumed innocent until proved guilty according to law”. Yet, it has been held in cases under the Sexual Offences Act 2003 that strict liability laws do not contravene the convention. Rather, Article 6 (2) is considered to be concerned with "the procedural fairness of a trial, not with the substantive law that falls to be applied at the trial.” (Summarised by Lord Phillips CJ at CA judgment para 23 R v G [2008] UKHL 37; [2009] 1 AC 92). 


\section{The Police implementation of Section 14}

With the introduction of new laws the police must consider how the legislation should be implemented to deal with the new offence specified. The CPS Legal Guidance on charging under section 14 is clear that it should not normally be used for kerb crawling:

It is anticipated that this [section 14] offence will be considered most often in relation to off-street prostitution. If the police apprehend someone who has paid for sexual services with a person involved in street prostitution, it is likely that soliciting (section 51(A) Sexual Offences Act 2003 - see Kerb Crawling below) would be a more appropriate offence to pursue as this does not require proof of exploitative conduct.

The offence is most likely to arise in police brothel raids where there is enforcement against suspects controlling or exploiting prostitution for gain and where clients are apprehended in the operation (CPS 2010, p.12-13).

but the Home Office report that:

This offence came into effect on 1 April 2010. As of June 2011, the Crown Prosecution Service has identified that, since its enactment, 40 offences have been charged, which include cases of kerb crawling (HMG 2011, p.94).

This accords with information which was already in the public domain. For instance

Gavin Shuker (Luton South, Labour MP) in a House of Commons Debate on 19

November 2012 (House of Commons Debate c292W) made a request for information regarding the number of convictions under the act. Jeremy Wright (Kenilworth and Southam, Conservative MP) provided information about the number of defendants found guilty and sentenced at all courts, with sentence breakdown, for offences under section 14 of the Policing and Crime Act 2009: 
TABLE 1

The number and types of convictions under S.14Policing and Crime Act 2009 between its implementation and 19 November 2012

\begin{tabular}{l|c}
\hline Conviction & Number of Convictions \\
\hline Found guilty & 43 \\
\hline Sentenced & 43 \\
\hline Other sentences & 14 \\
\hline Fine: Maximum available fine (£1,000) & 29 \\
\hline & \\
(Source: House of Commons Debate, 19 & \\
November 2012, c292W) & \\
\hline
\end{tabular}

Others have used the Freedom of Information Act 2000 to ascertain the number of times section 14 has been used (see e.g. Mr Silver in 2011, Whatdoweknow.com). We believe ours has been the first attempt to look at how individual police forces in England and Wales are implementing the section and the results suggest the overwhelming majority of forces are not using it.

\section{Inconsistent application - statutory interpretation}

In order to determine whether the new strict liability law is being used and how it was being implemented, we made a request under the Freedom of Information Act 2000 to gain information in respect of section14 of the Policing and Crime Act 2009. In particular we sought to gain information regarding:

1. The number of times s.14 of the Policing and Crime Act 2009 has been used since the act became law,

2. Details of the use of this section of the Act e.g. reasons for use of this law,

3. The outcome of the use of this section of the Act, e.g. whether formally charged, fined or otherwise.

Letters containing requests for this information were sent to all Chief Constables across the 43 police forces in England and Wales in June 2012. 
Under the Freedom of Information Act polices forces were required to respond to the request letters within the 20 working days of receipt of the letter. In the majority of cases, police authorities’ responded within the 20 day period. Others acknowledged our request and sent information a short period after the acknowledgement, whilst a minority did neither acknowledge nor reply to our request. On these occasions, we once again wrote to each of the police forces that did not reply to remind them of their obligation to reply to us under the Freedom of Information Act. From this request, 35 police forces have replied saying that they hold no recorded information, 2 forces have not replied despite being sent reminder letters, 2 forces sought clarification in terms of the Home Office Offence codes, 2 forces acknowledged our requests but did not provide information and 2 forces had used the law.

This process has not least demonstrated the difficulties in gaining information under the Freedom of Information Act 2000, despite this being a statutory requirement. Some police forces responded to us immediately whilst others appeared to ignore our request for information, despite us sending reminder letters and emails. In some instances we were asked to clarify which of the Home Office Offence codes we wanted information about because 'Section 14 of the Policing and Crime Act 2009 is too broad and we do not record offences on the policing system as Section 14, they are categorised into offences codes (Home Office Offence Codes)' (Communication dated 2 July 2013).

From these requests, it was apparent that since its introduction section 14 had not been used by the majority (81\%) of police forces across England and Wales, which in itself questions the need for the new strict liability offence. Whether this suggests that this law is not needed because the police had not found instances where 
a person had been subject to force, coercion or abuse because this rarely occurs, or whether they were unable or unwilling to detect such cases and utilise their discretion to apply the law, is open to debate.

Research has suggested that the police do often utilise their discretion to deal with violence and abuse cases. For instance, in the context of rape cases, Dellinger Page (2010:315) found that despite 'significant advancements in rape law reform ... police officers sometimes fail to adopt these changes'. In some instances police demonstrated acceptance of rape myths and others expressed sexist attitudes. Police attitudes towards sex workers has highlighted that some officers view prostitutes as offenders rather than as victims (Kingston, 2013). Thus, negative attitudes towards sex workers could inform police officers reluctance to utilise law which in some instances positions them as victims of abuse and exploitation.

Further research has demonstrated that sex workers are often the victims of rape, yet this is often not reported to the police (McKeganey \& Barnard, 1996) because they fear the police will not take their claims seriously or believe that they are in some way responsible for their own victimisation (Miller \& Schwartz, 1995). Likewise, 'trafficked women are reluctant to report their exploitation to the police for fear of reprisals from traffickers, and because of their inherent distrust of the authorities' (Goodey, 2004, p.28). These fears that their accounts of abuse may not be taken seriously could be the result of prior experience, myths or sex worker's own personal fear because of their stigmatised and criminalised position in society. Police crackdowns and brothel raids have been known to deter prostitutes from reporting violence or thefts to the police because of fear of prosecution (Sanders 2005). The lack of application of the strict liability offence may therefore have been informed by 
sex workers themselves, who were in fear of potential prosecution, and therefore did not report their victimisation.

Fears of traffickers or captors may have also impacted on victims’ reluctance to report their abuse to the authorities. Research has shown that traffickers use violence and intimidation to control their victims (Hodge \& Lietz, 2007). Some victims have suffered physical violence from their captors; others are threatened or told that their family and friends would be targeted if they did not comply with their demands. Indeed, the control and power that traffickers can have over their victims can hinder the police's ability to tackle the issue. Critics of the Swedish model have argued that the criminalization of the purchase of sex in Sweden has made sex workers more vulnerable to exploitation (Fouche 2007). The police in Sweden have commented that the law has driven women into the hands of pimps and made it harder for the police to prosecute violent men, including traffickers (Fouche 2007).

Police detection of trafficking has also been questioned in the context of research and evidence which has demonstrated that the police are unable to detect whether someone has been the victim of sexual exploitation. As Goodey (2004, p.28) describes "the police and immigration officials are ill-equipped to recognize and respond to the problem as one involving victims as well as offenders”. A recent study by the Centre for Social Justice (CSJ, 2013, p.21) demonstrated their concerns over a lack of knowledge and awareness of trafficked victims:

The CSJ has been shocked at the low awareness among professionals and has seen that many are not equipped to fulfil their responsibility. We have encountered unacceptable levels of ignorance and misidentification of victims among the police, social services, the UKBA, the judicial system and others whose responsibility is to identify victims and ensure they are protected. This is a grave hindrance to the UK's response to the victims hidden within its communities and the traffickers who seek to exploit them. 
Thus, the police may not know whether someone is the victim of trafficking, due to both the difficulties in terms of detecting this, but also because of their ignorance and lack of training in this area. The lack of use of this law could be a reflection not of the lack of need for the law, but because it is difficult to implement. One example of this lack of awareness and its impact in terms of practice is highlighted by a comment made by a Deputy Chief Constable, in evidence to the CSJ

'One girl escaped from a brothel and went to a police station to tell them that she had been trafficked. She had no passport. Under these confusing circumstances, we chose to arrest her for being an illegal immigrant.' (cited in CSJ, 2013, p.21).

Sex worker rights groups such as the English Collective of Prostitutes and the UK Network of Sex Work projects have previously highlighted this concern; that women found to be the victims of trafficking had been deported back to the country that they had been trafficked from, which it may be argued, could result in the victims being retrafficked to another country or punished by their traffickers for being caught. This raises significant questions about the UK's concerns over sex trafficking for sexual exploitation when those found to be victims are not supported, but are rather shipped back to the country that they were trafficked from. In one case, a Moldovan woman who was the victim of sex trafficking, won damages from the Home Office after she was deported back home where she was at risk from her traffickers (Travis, 2011). It was argued that sending the woman back to Moldova violated her human rights.

The final consideration is that the law is not being used because the extent to which sex trafficking occurs has been exaggerated and the number of women subjected to force, deception or threats is smaller than initially anticipated. This is 
supported by research which has indicated that only 13 per cent of women in one study of migrant sex worker had experienced some form of exploitation, ranging from extreme cases of trafficking to relatively more consensual arrangements (Mai 2009:32). According to the report, only a minority (6\%) felt that they had been deceived and forced into selling sex in circumstances within which they had no control (Mai 2009:32). Furthermore, findings of the government's own national police operations Operation Pentameter and Operation Pentameter 2, also revealed that the extent of abuse, sexual exploitation and trafficking is nowhere near at the level originally quoted by former Foreign Office minister, Denis MacShane, of 25,000 sex slaves in the UK (Davies 2009a). Following raids on 515 premises Operation Pentameter found 84 women to be trafficked victims and 188 women were 'rescued' (Gloucestershire Constabulary 2006). Similarly, during Operation Pentameter 2 raids on 822 brothels, flats and massage parlours found only 167 'victims'. Of the 528 arrests made, only 22 people (4\%) were finally prosecuted for trafficking, seven of which were eventually acquitted. Davies (2009b) argues that this is evidence of a moral panic, as after all these efforts a total of only 15 men and women were prosecuted of trafficking offence. In this sense "given that trafficking has been cited as the reasoning behind the law it does not appear to make sense to introduce legislation which has the potential to criminalize a large proportion of men when evidence suggests that it is not as endemic as previously thought” (Kingston, 2010, p.32).

For the two police forces that had utilised S.14 of the Policing and Crime Act 2009, Thames Valley made 66 arrests since s14 introduction and June 2013: 
TABLE 2

Number of Offences where an offender has or promised to pay for sexual services of a prostitute since 01/04/10

\begin{tabular}{l|c|c|c}
\hline Police Offence Disposal Description & $\mathbf{2 0 1 0 / 1 1}$ & $\mathbf{2 0 1 1 / 1 2}$ & $\mathbf{2 0 1 2 / 1 3}$ \\
\hline Adult Restorative Disposal & & & \\
\hline Adult Simple Caution & 4 & 1 & 0 \\
\hline Offender charged or summons served & 36 & 1 & 7 \\
\hline No further Action & 8 & 0 & 0 \\
\hline Still in progress & 0 & 0 & 3 \\
\hline Total & $\mathbf{4 8}$ & $\mathbf{7}$ & $\mathbf{1 1}$ \\
\hline (Source: Thames Valley Constabulary, 2013) & & & \\
\hline
\end{tabular}

It appears that Thames Valley police particularly utilised this law in the first year it was implemented, which may suggest that the decline in use was a result of the police crackdown in 2010 (demand was thereby deterred) or that this higher use of the law was simply a result of the introduction and 'novelty' of use of the new law. Further investigation would be needed to determine why these variations have occurred.

In contrast, in Avon and Somerset, there have been 81 arrests relating to this offence since the implementation of the law and June 2012 (Avon and Somerset Police, 2012). This on the surface seems to suggest that the law has been utilised and could provide evidence for its use for dealing with the offence prohibited under the law. However, in response to our request for details of the use of this section of the Act e.g. reasons for use of this law it was identified by Avon and Somerset police that the arrests were all made for the following reason: "Solicit another for the purpose of obtaining their sexual services as a prostitute in a street / public place”. This, under the terms of the law is an incorrect application of the strict liability offence, as this offence is already covered under S.51 of the Policing and Crime Act. Under section “51A Soliciting (1)It is an offence for a person in a street or public place to solicit another (B) for the purpose of obtaining B's sexual services as a prostitute”. 
Avon and Somerset's Crown Prosecution Service (CPS) must have also become aware of this mis-application, because a number of the outcomes of the arrests made by Avon and Somerset police would have gone through the courts, such as fines or Anti-Social Behaviour Orders. As our response from Avon and Somerset police indicates there were a number of outcomes, some of which the CPS would have been directly involved in:

TABLE 3

The Outcomes and Numbers of Arrests made under S.14 Policing and Crime Act since its implementation by Avon and Somerset Constabulary in July 2012

\begin{tabular}{l|c}
\hline \multicolumn{1}{c|}{ Outcome Number of Arrests } & Number of Arrests \\
\hline Discontinuance & 1 \\
\hline Conditional Discharge & 2 \\
\hline Fine & 2 \\
\hline Simple Caution & 2 \\
\hline ASBO, Fine \& Costs & 3 \\
\hline Fine \& Costs & 9 \\
\hline No Further Action & 12 \\
\hline Conditional Caution & 50 \\
\hline & \\
(Source: Avon and Somerset Constabulary, & \\
2012) & \\
\hline
\end{tabular}

Conditional Cautions and outcomes requiring a court hearing such as those leading to fines, costs, and conditional discharges would all involve the CPS. Yet the involvement of the CPS would be inconsistent with the Legal Guidance produced by the CPS for its staff. The police force in question is adamant that they are using section 14 for street soliciting when, as we reported above, the Legal Guidance is equally adamant that:

It is anticipated that this [section 14] offence will be considered most often in relation to off-street prostitution. If the police apprehend someone who has paid for sexual services with a person involved in street prostitution, it is likely that soliciting (section 51(A) Sexual Offences Act 2003 - see Kerb Crawling 
below) would be a more appropriate offence to pursue as this does not require proof of exploitative conduct. (CPS 2010, p.1)

Our attempts to get the relevant CPS office to elaborate on this seeming inconsistence have met with no response. We wrote to Avon and Somerset CPS who stated that they would 'respond within the next 15 working days', yet to date we have yet to receive a reply (Communication dated 15 November 2012).

If this use of section 14 becomes a standard use by the police in relation to behaviour that should be charged under section 51(A) it would not be the first time the police and other agencies have stretched the black letter of the law in directions it was not supposed to go in. The HM Inspectorate of Constabulary has recently described the police misuse of stop and search laws as 'alarming', with some $27 \%$ of them reported to be without sufficient grounds to justify the lawful use of the powers (HMIC 2013, p.6) and some lawyers have admitted using the 1997 Protection from Harassment Act, designed to combat stalkers, to deter protestors in certain situations (Lewis and Evans 2009). The use of Anti-Social Behaviour Orders (ASBOs) on people with mental health problems and even Alzheimer's disease has been widely criticised as a misuse of the laws in question (Hack 2009).

\section{Discussion}

The requests made under the Freedom of Information Act 2000 to all 43 police forces across England and Wales has demonstrated that the majority have not used s14 of the Policing and Crime Act 2009. This raises questions about the need for this law and/or the inherent difficulties the police have in identifying women who have been trafficked for sexual exploitation. It also makes the one force who say they have used 
it some 81 times to make arrests all the more interesting. Given that this police force has utilised the law, in what appears to be an inappropriate manner, further research and questions need to be raised about this incorrect application of the law to offences already covered under existing legislation. As already shown, mis-application of the law is not uncommon, but needs to be fully investigated to determine whether this was intentional or not, as this raises further questions about police officers and forces intentions given that s.14 is one of strict liability and may therefore be more easily utilised.

The lack of police use of the law also challenges some of the fundamental principles upon which the legislative changes were made. In particular, the rationale of reducing the demand for prostitution because it is often considered to be fuelling sex trafficking is under scrutiny. Supporters will no doubt suggest that the lack of application of the law demonstrates very clearly that the law is working, that demand has been reduced as clients are deterred by the legal changes and potential punishments they may face. Yet previous research has demonstrated that police crackdowns on kerb-crawlers for instance, have meant that they often 'simply go elsewhere' rather than end their offending behaviour (Sanders, 2009, p.6). Similarly, sex workers have been known to displace to other areas when the police target a particular location, which can sometimes undermines their ability to stay safe (Kinnell, 2008; Sanders, 2005). Other than the non-use of the strict liability offence, no other evidence suggests that this law has been effective in deterring demand or reducing the prevalence of prostitution.

Furthermore, the suggestion that the law was needed to protect vulnerable individuals has been questioned given that the extent of trafficking for sexual exploitation has not been found to be an endemic as originally thought. Some may 
argue that this is because the police are unable to detect such instances, which would suggest gross incompetence across the majority of police forces across England and Wales. Others may suggest that this is an accurate reflection of its extent in the UK. What we do know is the law is not being used.

\section{Bibliography}

Avon and Somerset Constabulary (2012) S.14 Policing and Crime Act 2009 (Stats Arrests), Available at:

http://www.avonandsomerset.police.uk/information/foi/QandA_Question.aspx?qid=1 $\underline{868}$ [accessed 11 July 2013].

BBC News (2009) 'Smith accused over prostitute law' BBC News, [Online 19 May] Available at: http://news.bbc.co.uk/1/hi/uk/8056767.stm [accessed 3 June 2009].

Carline A (2010) 'Critical Perspectives on the Policing and Crime Act 2009: An Unethical Approach to the Regulation of Prostitution?', Contemporary Issues in Law, 10 (2), 77-100.

Carline A (2011) ‘Criminal justice, extreme pornography and prostitution: protecting women or promoting morality?', Sexualities, 14, 312-333

Carline A (2011) 'Constructing the Subject of Prostitution: a Butlerian Reading of the Regulation of Sex Work', International Journal for the Semiotics of Law, 24, 61-78 
Council of Europe (2005) Convention on Action against Trafficking in Human Beings, Treaty Series no. 197

Davies, N. 2009a 'Inquiry fails to find single trafficker who forced anybody into prostitution' The Guardian, Tuesday 20 October 2009.

— 2009b 'Prostitution and trafficking - the anatomy of a moral panic' The Guardian, Tuesday 20 October 2009.

Dellinger Page, Amy. (2010) 'True Colors: Police Officers and Rape Myth Acceptance', Feminist Criminology, 5(4), 315-34.

Fouche, G (2007) 'Prostitutes fume as Norway bids to criminalise sex purchases' The Sunday Times Online, [Online Sunday, 22 July 22, 2007] Available at:

http://sundaytimes.lk/070722/International/i511.html [accessed 3 December 2009].

Goodey, Jo (2004) 'Sex trafficking in women from Central and East European countries: promoting a 'victim-centred' and 'woman-centred' approach to criminal justice intervention’, Feminist Review, 76, 26-45.

Hack C (2009) Mental health charity SANE has criticised an ASBO given to a man with schizophrenia taken to court by Waltham Forest police The Guardian 17 August House of Commons Debate (2012) Policing and Crime Act 2009, House of Common Hansard Written Answers 19 November 2012, Available at: 
http://www.publications.parliament.uk/pa/cm201213/cmhansrd/cm121119/text/12111 9w0004.htm\#12111924003487 [accessed 11 July 2013].

HMG (2011) Human trafficking: the government's strategy London, July.

HMIC (HM Inspectorate of Constabulary) (2013) Stop and Search Powers: are the police using them effectively and fairly, July, London.

Home Office (2002) Protecting the Public: strengthening protection against sex offenders and reforming the law on sexual offences, Cm 5668, November, London.

Home Office. 2004. Paying the Price: A Consultation Paper on Prostitution, Home Office Communication Directorate. July 2004. London: HMSO.

Home Office (2006) A Coordinated Prostitution Strategy London: HMSO.

Home Office (2007) UK Action Plan on Tackling Human Trafficking, London: HMSO: March 2007.

Home Office (2008) Tackling Demand for Prostitution: A review, London Home Office (2010) Provisions in the Policing and Crime Act 2009 that relate to prostitution (sections 14 to 21) (circular 006/2010), London. 
House of Commons (2009) House of Commons Hansard Debates for 19th May (pt 0016)', Available at:

http://www.publications.parliament.uk/pa/cm200809/cmhansrd/cm090519/debtext/90 519-0016.htm [accessed 3 June, 2009].

Human Rights Joint Committee (2009) Legislative Scrutiny: Policing and Crime Bill Human Rights Joint Committee Contents, Available at:

http://www.publications.parliament.uk/pa/jt200809/jtselect/jtrights/68/6805.htm [accessed 20 December 2009].

Kinnell, Hillary (2008) Violence and Sex Work in Britain. Cullumpton: Willan Publishing.

Kingston, S (2010) 'Intent to criminalize: Men who buy sex and prostitution policy in the UK', New Sociologies of Sex work, K. Hardy, S. Kingston \& T. Sanders (Eds.), Ashgate.

Kingston, S (2013) Prostitution in the Community: Attitudes, Action and Resistance, London: Routledge.

Lewis P and Evans R (2009) High Court Injunctions - the weapon of choice to stop protests The Guardian 27 October

Liberty (2009) evidence to the Committee looking at the Bill 
Mai, Nick (2009) Migrant Workers in the UK sex industry: Final Policy Revevant Report, ESRC funded project, Available at: http://www.londonmet.ac.uk/researchunits/iset/projects/esrc-migrant-workers.cfm [accessed 21 April 2010].

McKeganey, N, and M Barnard (1996) Sex Work on the Streets: Prostitutes and their Clients. Buckingham: Open University Press.

Miller, J, and M Schwartz (1995) 'Rape myths and violence against street prostitutes' Deviant Behaviour: An Interdisciplinary Journal, 16, 1-23.

Politics.co.uk (2009) 'Policing and Crime Bill' Politics.co.uk, [Online 17 May] Available at: http://www.politics.co.uk/legislation/policing-and-crime-bill\$1296338.htm [accessed 3 June, 2009].

R v G [2008] UKHL 37; [2009] 1 AC 92

Sanders, T. (2009) 'Kerbcrawler rehabilitation programmes: Curing the "deviant” male and reinforcing the “respectable” moral order’, Critical Social Policy, 29 (1),7799.

Whatdoweknow.com (2011) Prostitution Convictions, Available at: https://www.whatdotheyknow.com/request/prostitution_convictions [accessed 11 July 2013]. 